\title{
Process of Resolving Cases of Traffic Violations which Resulted Death
}

\section{Hendri Listiawan Nugroho*) and Achmad Sulchan**)}

*) Student of Master of Law, Faculty of Law, Universitas Islam Sultan Agung (UNISSULA) Semarang, E-mail: elrasyid.jr@gmail.com

${ }^{* *}$ Faculty of Law, Universitas Islam Sultan Agung (UNISSULA) Semarang

\begin{abstract}
.
A traffic violation is an act that is contrary to traffic and/or its implementing regulations, which may or may not cause loss of life or property as well as security, order and smoothness of traffic (kamtibcarlantas). This writing aims to identify and analyze the process of resolving cases of traffic violations that cause people to die based on, constraints, and solutions in solving cases. The approach method used is a sociological juridical approach. The research specification used is descriptive analysis, primary and secondary data sources and uses qualitative analysis. This writing is analyzed with the theory of justice and the theory of legal certainty to answer the problem. The process of settlement of cases is carried out in accordance with the criminal procedure law as regulated in the Criminal Procedure Code (KUHAP), starting from investigations, investigations, prosecution by the Public Prosecutor, and trials in court where criminal decisions are subsequently sentenced to the perpetrators. The obstacles faced include: inadequate infrastructure, lack of human resources, lack of coordination between the police and prosecutors, lack of public legal awareness, and lack of compliance with legal rules by the community. The solutions applied were in the form of: completing the facilities and infrastructure, improving the quality of human resources, improving coordination between the police and prosecutors, holding outreach to the public. Keywords: Implementation, Traffic Violation, Death of People
\end{abstract}

\section{Introduction}

Indonesia is a state based on law, a country whose governance is based on law. In a rule of law, the power to run the government is based on the rule of law and aims to carry out law order. A rule of law is a social organization that aims with its power to regulate and organize a society. ${ }^{1}$ Meanwhile, according to Achmad Ali, law is a set of rules or measures that are arranged in a system to determine what can and cannot be done by humans as citizens in their social life. ${ }^{2}$

The law is the whole rule of behavior that applies in a life together, which can be enforced with a sanction. ${ }^{3}$ Traffic accidents are still a serious problem in developing and developed countries. The death rate according to WHO has reached

\footnotetext{
${ }^{1}$ Lubis, M. Solly. (2002). Ilmu Negara, print-5. Bandung: Mandar Maju. p. 1

${ }^{2}$ Ali, Achmad. (2002). Menguak Tabir Hukum (Suatu Kajian Filosofis). Jakarta: PT. Toko Gunung Agung Tbk. p. 3

${ }^{3}$ Mertokusumo, Sudikno. (2008). Mengenal Hukum (Suatu Pengantar). Yogyakarta: Liberty, print-4, p. 40
} 
$1,170,694$ people worldwide. This number is equivalent to $2.2 \%$ of the total number of deaths in the world and reaches the ninth out of ten causes of death. ${ }^{4}$

Law enforcement is the application of law in various aspects of the life of the nation and state in order to create legal order and legal certainty oriented towards justice. Law enforcement in a narrow sense can be interpreted as a series of activities within the (criminal) justice system that are preventive, repressive and educational in nature. Law enforcement as the basis for upholding the rule of law, not only requires a commitment to the obedience of all components of the nation to the law, but requires law enforcement officials to enforce and guarantee legal certainty. ${ }^{5}$ Various controversial cases have appeared in public, either through media coverage, newspapers or the internet in connection with the criminal case settlement process. ${ }^{6}$

\section{Research Methods}

The approach method used in this research is the sociological juridical approach to study and discuss the issues raised, namely by linking law to efforts to achieve goals and meet the needs of society. The research specification used is descriptive analysis ${ }^{7}$, primary and secondary data sources, and use qualitative analysis.

\section{Result and Discussion}

\subsection{Settlement of cases of traffic violations that have resulted in the death of people}

According to the provisions of the Criminal Procedure Code there are three procedures for examination in resolving criminal cases, namely: Ordinary Examination Procedures, Short Examination Procedures and Quick Examination Procedures. The three Audit procedures are carried out based on the style of the case it receives, so that if the type of case received is an ordinary case then it must also be resolved using an ordinary examination procedure, if it is a type of case based on Article 203 of the Criminal Procedure Code, then the procedure used is a Short Audit Procedure. However, if the case is a case punishable by imprisonment or a maximum imprisonment of three months and or a maximum fine of seven thousand and five hundred rupiahs and minor insults and road traffic offenses, then the case must be resolved by a speedy examination procedure. ${ }^{8}$

\footnotetext{
4Pietersz. (2010). Karakteristik Surat Tilang dalam Penindakan Pelanggaran Lalu Lintas \& Angkutan Jalan. Jurnal Sasi Vol. 16 No. 3 in July - September 2010, p. 331

${ }^{5}$ Santoso, Yosy Budi \& Umar Ma"ruf. (2017). Kebijakan Pembuktian \& Penuntutan Oleh Jaksa Penuntut Umum Dalam Pemberantasan Tindak Pidana Korupsi, Jurnal Hukum Khaira Ummah Vol. 12 No.2, p. 360

${ }^{6}$ National Police Headquarters of the Republic of Indonesia Police Academy, (2009). Fungsi Teknis Lalu Lintas. Semarang: Kompetensi Utama, p. 6

${ }^{7}$ Sumawarni, Sri. (2012). Sebuah Seri Metode Penelitian Hukum. Semarang: UPT UNDIP Press. p.6 ${ }^{8}$ Muhammad, Rusli. (2013). Lembaga Pengadilan Indonesia Beserta Putusan Kontroversial, Yongyakarta: UII Pres.p. 6
} 
The procedures for rapid examination as stipulated in the Criminal Procedure Code include procedures for examining minor crimes and cases of traffic violations. Article 211 of the Criminal Procedure Code states that what is examined according to the traffic violation examination procedure is a certain traffic violation against the traffic laws and regulations. ${ }^{9}$ From the explanation regarding the provisions stipulated in Article 211 of the Criminal Procedure Code, it can be seen that what is meant by certain violation cases are:

- Use the road in a way that may obstruct, endanger traffic order or safety or which may cause damage to the road.

- Driving a motorized vehicle that cannot show a driving license (SIM), vehicle registration certificate, valid vehicle test certificate or other evidence required according to the provisions of road traffic legislation or he can show it but the validity period has expired.

- Allowing or allowing a motorized vehicle to be driven by a person who does not have a driver's license

- Failure to comply with the provisions of the road traffic laws regarding numbering, weighing, equipment, equipment, vehicle loading and the conditions for mixing with other vehicles.

- Allowing an existing motorized vehicle to be on the road without having a license plate for the vehicle's number concerned. Violation of orders given by road traffic controllers, and road traffic control signals, signs or existing signs are used on the road.

- Violation of the provisions regarding the size and allowable cargo, how to load and unload passengers and/or how to load and unload goods.

- Offense to the route permit, the type of vehicle allowed to operate on the specified road. ${ }^{10}$ This is in a manner detail that is meant by cases of certain violations of road traffic, which are examined in a court session by means of examination of cases of road traffic violations conducted by procedures for rapid examination. ${ }^{11}$

Criminal requirements generally include requirements relating to aspects of the act and of the person. These two aspects are the two most paired principles, namely the principle of legality which concerns the aspect of action and the principle of culpability regarding the principle of error concerning the aspect of the person. The legality principle requires definite provisions first, while the guilt principle requires that only those who are truly guilty are subject to punishment. Settlement of cases of traffic violations that led to their death is resolved through the Court. ${ }^{12}$

\subsubsection{Pre-Investigation}

\footnotetext{
${ }^{9}$ Samapto, Setio Agus. (2009). Penyelesaian Perkara Pidana di Luar Pengadilan Terhadap Dugaan Kejahatan Pasal 359 KUHP Dalam Perkara Lalu Lintas. Yongyakarta: Jurnal STMIK AMIKOM.p. 5 10P.A.F. Lamintang, Theo Lamintang. (2013). Pembahasan KUHAP Menurut Ilmu Pengetahuan Hukum Pidana \& Yurisprudensi. Jakarta: Sinar Grafika.p. 467

${ }^{11}$ Harahap, M.Yahya. (2005). Pembahasan Permasalahan \& Penerepan KUHAP. Jakarta: Sinar Grafika.p. 434

12 Interview with Nani Pratiwi, SH as the Junior Primary Judge at the Brebes District Court, on 15 September 2020
} 
A series of actions by investigators to search for and find an event that is suspected of being a criminal act in order to determine whether or not an investigation can be carried out according to the manner regulated in the Criminal Procedure Code.

\subsubsection{Investigation}

An investigation is considered complete if within fourteen days the public prosecutor does not return the results of the investigation or before that time has ended, there has been a notification (because according to Article 138 paragraph (1) within seven days the public prosecutor is obliged to notify the investigator whether the results of the investigation are complete or not, regarding this matter from the public prosecutor to the investigator (Article 110 paragraph (4) KUHAP).

\subsubsection{Prosecution}

The action of the public prosecutor to delegate a criminal case to the competent court in the case according to the manner stipulated in the Criminal Procedure Code with a Request for Examination and Decision by a Judge in Court Session

\subsubsection{Court}

Inspection process case If the District Court receives a case delegation letter from the public prosecutor and believes that the case is within its authority, the Head of the District Court then appoints the judge who will hear the case and the appointed judge determines the day of trial (Article 152 paragraph 1 KUHAP).

\subsection{Constraints and Solutions Faced When Resolving Cases of Traffic Violations That Cause Death Of People}

The settlement of cases of traffic violations which caused the death of people did not immediately proceed as expected by all parties (Law Enforcement Officials, Defendants, and Victims), however in resolving this case there were several obstacles that were experienced during the settlement process, including :13

\subsubsection{Facilities and infrastructure}

Support for the availability and readiness of facilities and infrastructure is an important part of supporting the smooth delivery of court services, both in relation to the technical administration of trials and court administration. Support for these pre-facilities is also a prerequisite for the smooth running of traffic violations cases. Moreover, in some areas the number of traffic violation cases has reached a large number which has implications for the real need for the availability of supporting facilities. In some courts there are still no special counters for ticketing services. Some are still in the form of a special ticket service room, not a ticket window. Some of the others are still combined with other case management or service counters.

\subsubsection{Limited Human Resources}

\section{Ibid.}


In cases of traffic violations, it is often found that the large number of cases is not comparable to the workforce handling these cases. However, in cases of traffic violations that resulted in the death of people, sometimes the handling is still short of staff to handle this case because the number of cases in the Court has piled up. In addition, if staff must be involved, human resources are considered ineffective.

\subsubsection{The effectiveness of service coordination with the Police and Prosecutors}

In order to support the smoothness and effectiveness of the management of traffic cases that lead to the death of people, cooperation between institutions, be it courts, police or prosecutors, is a must that should be encouraged and optimized. Such cooperation should also be built in the building of an integrated criminal justice system. Where the essence is the existence of integration and harmony between the criminal justice sub-systems. Whether one sub-system runs smoothly or not will affect the other sub-systems. The integrity of the institution can be constructed in terms of (i) organizational, (ii) functional, and (iii) administrative. In practice, sometimes there is a lack of cohesiveness between the Police and the Prosecutor, which causes obstruction in the process of solving cases.

\subsubsection{Lack of legal awareness}

Initially, the understanding of this legal awareness comes from the community itself, which is a determining factor for the validity of the law. Legal awareness issues arise in the application process of written positive law. In this process problems arise, because of the mismatch between the legal basis of the law (namely social control from the authorities or the awareness of the community) and the fact that the written positive law can be obeyed (or not obeyed). It is a condition that is aspired to or desired, that there is a proportional harmony between social control by the authorities, the awareness of the community as the legal basis for written positive law, that there is no law that binds every citizen except on the basis of legal awareness.

If lawmakers create regulations that do not match people's awareness or feelings, it is expected that negative reactions from the community will arise. The greater the conflict between the rules and the awareness, the more difficult it is to enforce them. It is certain that the formation of the law treated him by force, and consequently increased the social costs incurred. On the other hand, if the regulations are in accordance with public awareness, then the problems in their implementation are almost non-existent. So that there is a very strong tendency, causing a proportional harmony between the law applied and the legal awareness of the community concerned.

Thus, the issue of legal awareness needs to receive deeper attention in Indonesia as a developing country which is moving towards a real globalization era. However, it needs to be acknowledged that apart from issues of legal awareness, there are other factors that need to be considered. This is because the attitude of citizens towards law is also influenced by factors of interest and a solid understanding of law by administrative organs. Rather, they reinforce the need to undertake research on legal awareness issues.

\subsubsection{Lack of compliance with law}


In the field of traffic regulation and road transportation, there is no reciprocal relationship between the level of knowledge about regulations and the level of knowledge about the contents of the regulations. Most people in the community do not know that a regulation exists, but they know its contents, because the contents are in accordance with the prevailing system of values because of the internalization process. So in this case a person obeys legal principles because intrinsically obedience has a reward, the result is conformity based on intrinsic motivation whose power center lies in the trust of citizens in the objectives of the legal principles concerned.

Compliance can occur why the internalization process appears in compliance, namely because most people do so and for the sake of smooth traffic. The basic authority also shows the positive influence of knowledge of the contents of the regulations on the compliance of these regulations. Compliance also appears high in following the regulations regarding motorized vehicle equipment and the obligations that must be carried out at the time of an accident, including responsibility for damages that occur to parts or road accessories as well as things that must be done when the vehicle is damaged. Quantitatively, there is a tendency that knowledge of the contents of regulations has a positive effect on legal compliance.

These constraints, as much as possible, find a solution in the settlement of the case so as not to cause harm to both parties. The solutions to these obstacles include: 14

- Facilities and infrastructure; Provision of adequate supporting facilities for the implementation of the trial, both public facilities and court facilities. The availability of facilities which constitute the minimum standard includes signs and information regarding the locations used in the operation of traffic violation services.

- Limited Human Resources; There are several solutions to overcome the limited human resources in handling ticket cases. One of them is the addition of court officers. Especially the staff who are responsible for the filing. Then, additional officers who are responsible for administrative services at the time of the trial. Also additional court officers in managing and securing queues from offenders. Temporary solutions that have been pursued with assistance from other units have the potential to cause problems with employee performance.

- The effectiveness of service coordination with the Police and Prosecutors; Improve performance in cooperation between the Police and the Attorney General's Office in handling cases of traffic violations that have resulted in the death of people so that the settlement of cases can be carried out as optimally as possible.

- Lack of legal awareness; Courts need to conduct socialization to increase legal awareness for the community, especially regarding traffic so that there are no deliberate violations by the community because the criminal sanctions seem ordinary and easy to carry out.

14 Ibid. 
- Lack of compliance with law; Courts need to schedule or carry out outreach, either directly or using pamphlets posted on the side of the road to urge the public to comply with the current law regarding road driving.

Efforts to create laws that are appropriate and in line with society without one party being harmed can be linked to the theory of justice. According to Aristotle in his Nicomachean Ethics, it is entirely aimed at justice as the core of legal philosophy, "because law can only be established in relation to justice. In connection with this, of course, the theory of justice is very relevant considering that law can only be enforced/applied in relation to justice. Especially when it is associated with one of the values of Pancasila, namely in the 5th principle of Pancasila which reads, "Justice for all Indonesian people".

Constraints experienced when resolving cases of traffic accident violations that cause death are resolved by paying attention to the values of justice so as not to harm the community.

\section{Conclusion}

The process of resolving cases of traffic violations that caused the death of people in Decision Number 152/Pid.Sus/2018/PN Bbs is carried out in accordance with the criminal procedure law as regulated in the Criminal Procedure Code (KUHAP), starting from investigation, investigation, prosecution by the public prosecutor, and proceedings at the court to subsequently impose a criminal verdict against the perpetrator. The constraints faced include: inadequate infrastructure, lack of human resources, lack of coordination between the police and prosecutors, lack of public legal awareness, and lack of compliance with legal rules by the community. The solutions applied in dealing with these obstacles are in the form of: completing the facilities and infrastructure according to minimum standards, increasing the quality of human resources.

\section{References}

Journals:

[1] Santoso, Yosy Budi \& Umar Ma"ruf. (2017). Kebijakan Pembuktian \& Penuntutan Oleh Jaksa Penuntut Umum Dalam Pemberantasan Tindak Pidana Korupsi, Jurnal Hukum Khaira Ummah Vol. 12 No.2

[2] Samapto, Setio Agus. (2009). Penyelesaian Perkara Pidana di Luar Pengadilan Terhadap Dugaan Kejahatan Pasal 359 KUHP Dalam Perkara Lalu Lintas. Yongyakarta: Jurnal STMIK AMIKOM

[3] Pietersz. (2010). Karakteristik Surat Tilang dalam Penindakan Pelanggaran Lalu Lintas \& Angkutan Jalan. Jurnal Sasi Vol. 16 No. 3 in July - September 2010

Books:

[1] Ali, Achmad. (2002). Menguak Tabir Hukum (Suatu Kajian Filosofis). Jakarta: PT. Toko Gunung Agung Tbk

[2] Harahap, M.Yahya. (2005). Pembahasan Permasalahan \& Penerepan KUHAP. Jakarta: Sinar Grafika 
[3] Lubis, M. Solly. (2002). Ilmu Negara, print-5. Bandung: Mandar Maju

[4] Mertokusumo, Sudikno. (2008). Mengenal Hukum (Suatu Pengantar). Yogyakarta: Liberty, print-4

[5] Muhammad, Rusli. (2013). Lembaga Pengadilan Indonesia Beserta Putusan Kontroversial, Yongyakarta: UII Pres

[6] National Police Headquarters of the Republic of Indonesia Police Academy, (2009). Fungsi Teknis Lalu Lintas. Semarang: Kompetensi Utama

[7] P.A.F. Lamintang, Theo Lamintang. (2013). Pembahasan KUHAP Menurut Ilmu Pengetahuan Hukum Pidana \& Yurisprudensi. Jakarta: Sinar Grafika

[8] Sumawarni, Sri. (2012). Sebuah Seri Metode Penelitian Hukum. Semarang: UPT UNDIP Press

\section{Regulations:}

[1] Act No. 22 of 2009 concerning Road Traffic and Transportation

[2] Act No. 8 of 1981 concerning the Criminal Procedure Code

[3] Act No. 1 of 1946 concerning the Criminal Code

[4] The Draft Law on the Elimination of Sexual Violence

Interview:

Interview with Nani Pratiwi, SH as the Junior Primary Judge at the Brebes District Court, on 15 September 2020 